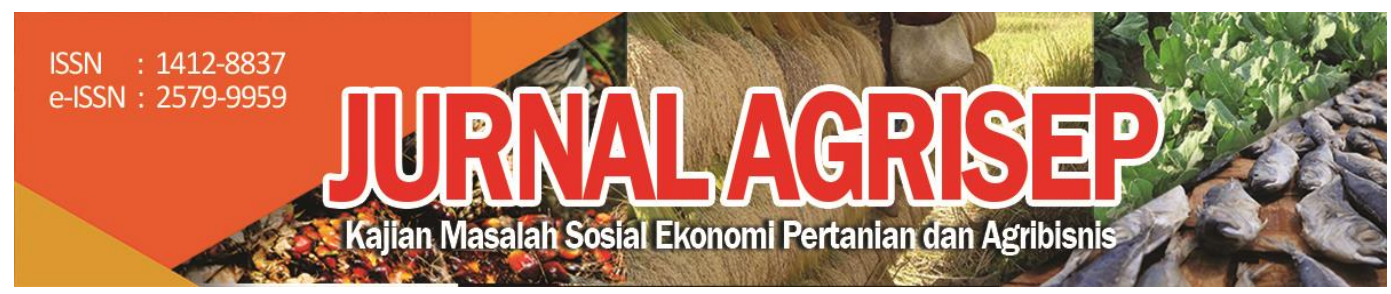

DOI: 10.31186/jagrisep.19.2.331-346

\title{
OPTIMALISASI PENGGUNAAN FAKTOR PRODUKSI PADA USAHATANI KAKAO DI KECAMATAN KUMPEH KABUPATEN MUARO JAMBI
}

\section{Optimization the Using of Production Factors of Cocoa Farming in Kumpeh District, Muaro Jambi District}

\author{
Dewi Sri Nurchaini1); Yusma Damayanti²); Riri Oktari Ulma3) \\ 1),2),3) Jurusan Agribisnis Fakultas Pertanian Universitas Jambi \\ Email : ryryady_ulma@yahoo.com
}

\begin{abstract}
This research was conducted in KumpehSubdistrict, Muaro Jambi District, with respondents being cocoa farmers. This research was conducted with the aim of: 1 . To know the description of the production function of cocoa farming 2. Analyzing the level of optimization / economic efficiency of the use of production factors in cocoa farming, and 3. Performing a calculation approach to determine the optimal use of production factors on cocoa farming. Farmers who were chosen as respondents were selected purposively, namely farmers who have cocoa at an optimal age of 9-14 years. The number of farmers who met these criteria was 55 people and the technique of taking respodentswas carried out by census. The analytical method used is the Cobb Douglas production function analysis, then the optimization calculation is continued with economic efficiency criteria, where the efficiency of the use of production factors is achieved if $N P M X i / H X i=1$. From the results of the analysis and discussion it can be concluded that: 1) The use of land production factors and technical / physical labor influences the increase in cocoa production / hectare / year, while fertilizers and medicines have no effect on production. 2) The use of factors of production of labor, fertilizers and medicines in cocoa farming is not yet economically efficient. 3) From the results of optimization, the use of work can be increased up to $238.5 \mathrm{HOK} /$ hectare / year or increased by 167.64 HOK from the actual workforce poured out by farmers. While the use of fertilizer $\left(X_{2}\right)$ can be added up to 2,293.28 kg / year / hectare or added 1,340.38 kg of actual use and medicines $\left(X_{3}\right)$ added to 9.50 liters or added 0.87 liters of the amount of drugs medicine used by farmers.
\end{abstract}

Keyword :Cocoa, Optimization, Profit maximizatio. 


\section{ABSTRAK}

Penelitian ini dilaksanakan di Kecamatan Kumpeh Kabupaten Muaro Jambi dengan responden adalah petani kakao. Penelitian ini dilakukan dengan tujuan : 1. Untuk mengetahui gambaran fungsi produksi pada usahatani kakao 2. Menganalisis tingkat optimasi/efisiensi ekonomi penggunaan faktor produksi pada usahatani kakao, dan 3. Melakukan pendekatan perhitungan untuk menentukan penggunaan faktor produksi yang optimal pada usahatani kakao. Petani yang dijadikan responden dipilih secara purposive yaitu petani yang memiliki kakao pada umur tanaman optimal 9-14 tahun. Jumlah petani yang memenuhi kriteria iniadalah 55 orang dan teknik pengambilan respoden dilakukan dengan sensus. Metode analisis yang digunakan adalah analisis fungsi produksi Cobb Douglas, kemudian dilanjutkan perhitungan optimasi dengan kriteria efisiensi ekonomi, dimana efisiensi penggunaan faktor produksi tercapai apabila NPMXi/HXi=1. Dari hasil analisis dan pembahasan maka dapat disimpulkan bahwa : 1) Penggunaan faktor produksi lahan dan tenaga kerja secara teknis/fisik berpengaruh terhadap kenaikan produksi kakao/hektar/tahun, sedangkan pupuk dan obat-obatan tidak memberikan pengaruh terhadap produksi. 2) Penggunaan faktor produksi tenaga kerja, pupuk dan obat-obatan pada usahatani kakao secara ekonomi belum efisien. 3) Dari hasil optimasi, penggunaan kerja dapat ditingkatkan hingga 238,5 HOK/hektar/tahun atau ditambah sebesar 167,64 HOK dari tenaga kerja aktual yang dicurahkan petani. Sedangkan penggunaan pupuk $\left(\mathrm{X}_{2}\right)$ dapat ditambah hingga sebesar 2.293,28 kg/tahun/hektar atau ditambah 1.340,38 kg dari penggunaan actual dan obat-obatan $\left(X_{3}\right)$ ditambah menjadi 9,50 liter atau ditambah 0,87 liter dari jumlah obat-obatan yang digunakan petani.

Kata Kunci:Kakao, Optimasi, Maksimisasi Profit

\section{PENDAHULUAN}

Indonesia merupakan Negara produsen ketiga terbesar kakao dunia setelah Evory Coast (Pantai Gading) dan Ghana. Peranan penting komoditi perkebunan ini dalam perekonomian nasional adalah penyedia lapangan kerja, sumber pendapatan petani dan penghasil devisa negara.Provinsi Jambi merupakan salah satu daerah penghasil komoditi kakao di Indonesia, perkebunan kakao di Provinsi Jambi tersebar di beberapa kabupaten dan yang menjadi sentra perkebunan kakao di kabupaten Muaro Jambi terdapat di kecamatan Kumpeh. Tercatat dari data Dinas Kehutanan dan Perkebunan Kabupaten Muaro Jambi, Provinsi Jambi pada tahun 2015, kecamatan ini memiliki total luas kakao yang paling terbesar dari kecamatan lainnya yaitu sebesar 503 ha dengan jumlah produksi sebesar 223 ton dan produktivitas sebesar 0,738 ton/ha.

Jenis kakao yang diusahakan petani di kecamatan Kumpeh adalah jenis forastero.Pada saat ini umur tanaman kakao berkisar antara 7 sampai dengan 16 tahun dan rata-rata jumlah pohon per hektar adalah 630 batang (Oktavia, 
2016).Menurut Siregar (1989) tanaman kakao mulai menghasilkanbuah pada tahun ke-3 dan produksi maksimal dicapai pada tahun ke-9 sampai dengan tahun ke-14. Pada saat rentang umur tersebut tanaman kakao mampu menghasilkan produksi hingga 1 ton per hektar dalamsatu tahun dan merupakan umur yang baik untuk menghasilkan produk yang maksimal. Dari keadaan di atas,tanam kakao di kecamatan Kumpeh pada saat ini masih berada pada rentang umur produksi yang optimal, namun produktivitasnya ternyata masih rendah.

Rendahnya produktivitas kakao yang dihasilkan di kecamatan Kumpeh mencerminkan petani setempat dalam berusahatani kakao belum menggunakan faktor produksi secara optimal. Dalam jumlah tertentu dari setiap faktor produksi, baik itu dari lahan yang digarap, kerja yang dicurahkan dan modal yang digunakan, belum bisa memberikan produksi yang maksimal. Pada tingkat harga produk dan harga faktor produksi yang given (tertentu), produksi yang maksimal dapat memberikan kontribusi dalam peningkatan pendapatan yang akan diterima petani.Perbandingan (rasio) harga output dan harga input yang optimal adalah suatu indikator pilihan untuk mencapai efisiensi ekonomi dalam berproduksi.

Di kecamatan Kumpeh kabupaten Muaro Jambi, harga komoditi kakao pada tahun 2014 dan 2015 adalah Rp 22.100 / kg, tingkat harga ini mengalami kenaikan dari harga kakao di tahun sebelumnya(Dinas Perkebunan Provisinsi Jambi, 2015). Sementara itu hal yang sama juga dialami pada harga pupuk dan obat-obatan. Tahun 2015 harga dari saprodi ini cenderung mengalami peningkatan dengan nilai tertinggi dibandingkan dengan harga pada empat tahun sebelumnya (Ketua Kelompok Tani Usaha Bersama Mandiri Kec. Kumpeh, 2015).

Untuk meningkatkan produktivitas kakao di kecamatan Kumpeh pada tingkat umur tanaman yang masih optimal,dimungkinkan kiranya untuk memahami prinsip hubungan input- output dalam membuat keputusan mengenai berapa jumlah faktor produksi yang harus di pakai petani untuk memperoleh produksi yang sebaiknya dihasilkan. Sebagai dasar pembuatan keputusan maka perlu diformulasikan fungsi produksi, sehingga dapat diketahui apakah penggunanaan faktor produksi pada usahatani kakao berada di tahap produksi yang optimal atau belum.

Tujuan Penelitian ini adalah (1) Untuk mengetahui gambaran fungsi produksi pada usahatani kakao di daerah penelitian, (2) Menganalisis tingkat optimasi/efisiensi ekonomi penggunaan faktor produksi pada usahatani kakao, (3) Melakukan pendekatan perhitungan untuk menentukan penggunaan faktor produksi yang optimal pada usahatani kakao. 


\section{METODE PENELITIAN}

\section{Tempat dan Waktu}

Penelitian ini dilaksanakan di Kecamatan Kumpeh dengan pertimbangan kecamatan tersebut memiliki produksi dan luas areal tanaman kakao terbesar di kabupaten Muaro Jambi. Pemilihan lokasi dilakukan secara sengaja (purposive).Objek penelitian ini difokuskan pada petani yang memiliki kakao dengan umur tanam yang optimal yaitu berkisar antara 9 - 14 tahun. Pelaksanaan penelitian ini dilaksanakan pada Bulan April sampai dengan bulan September Tahun 2019.

\section{Pengambilan responden}

Desa sampel yang dipilih pada penelitian ini adalah desa Pulau Mentaro dan Desa Betung. Menurut informasi dari Ketua Kelompok Tani dan PPL, jumlah petani yang memiliki tanaman kakao pada umur tanaman optimal ( 9 14 tahun) adalah 30 orang di desa Betung dan 25 orang di Desa Pulau Mentaro. Jadi dalam penelitian ini diambil jumlah petani responden dengan ukuran sampel sebesar 55 orang. Tehnik pengambilan responden pada penelitian ini dilakukan secara sensus.

\section{Pengumpulan data}

Jenis data yang dikumpulkan dalam penelitian ini meliputi data primer dan data sekunder. Data primer diperoleh secara langsung dari petani kakao. Sedangkan data sekunder diperoleh secara tidak langsung yaitu melalui laporan penelitian, bahan bacaan serta laporan dari instansi terkait yang ada hubungannya dengan penelitian.

\section{Analisis Data.}

Model analisis yang dipakai untuk mengetahui seberapa besar pengaruh penggunaan faktor produksi terhadap produksi kakao, adalah dengan analisis fungsi produksi Cobb Douglas yang formulasinya adalah

$$
\mathrm{Y}=\mathrm{aX}_{1}^{\mathrm{b} 1} \cdot \mathrm{X}_{2}^{\mathrm{b} 2} \cdot \mathrm{X}_{3}^{\mathrm{b} 3} \cdot \mathrm{X}_{4}^{\mathrm{b} 4} \mathrm{e}^{\mathrm{u}}
$$

Soekertawi (1994) menerangkan bahwa penyelesaian hubungan antara variabel $\mathrm{X}$ dan $\mathrm{Y}$ pada fungsi produksi Cobb Douglas dilakukan dengan menggunakan regresi. Untuk memudahkan pendugaan analisis maka persamaan fungsi Cobb Douglas diubah kedalam bentuk persamaan logaritma natural sebagai berikut:

$$
\operatorname{Ln} Y=\operatorname{Ln} a+b_{1} \operatorname{Ln} X_{1}+b_{2} \operatorname{Ln} X_{2}+b_{3} \operatorname{Ln} X_{3}+b_{4} \operatorname{Ln} X_{4}+\operatorname{Lnu}
$$


dimana $Y=$ Produksi kakao ( $\mathrm{kg} /$ tahun $/ \mathrm{ha}) ; \mathrm{X}_{1}=$ lahan (ha); $\mathrm{X}_{2}=$ Tenaga Kerja $(\mathrm{HOK}) ; \mathrm{X}_{3}=\operatorname{Pupuk}(\mathrm{kg}) ; \mathrm{X}_{4}=$ Obat-obatan (liter); $\mathrm{b}_{\mathrm{i}}=$ koefisien regresi (elastisitas produksi).

Nilai koefisien regresi dari persamaan, menggambarkan besarnya elastisitas produksi (bi) dari penggunaan faktor produksi. Dengan diketahui besarnya bi dan harga (produk dan faktor produksi)maka dapat dihitung tingkat optimasi/efisiensi ekonomi penggunaan faktor produksi pada usahatani kakao yang merupakan tujuan kedua dari penelitian ini.

Efisiensi ekonomi tercapai apabila NPMXi / HXi = 1. Apabila NMPXi/HXi kurang atau lebih besar dari 1 maka terjadi kondisi produksi yang tidak atau belum efisien (Doll dan Orazem 1978), Dikaitkan dengan nilai bi maka kriteria efisiensi ekonomi ini dapat dirumuskan sebagai berikut:

$$
\mathrm{IE}=\frac{\mathrm{bi} \cdot \frac{\mathrm{Y}}{\mathrm{X} i} \mathrm{Hy}}{\mathrm{Hxi}}=1
$$

dimana, IE= Tingkat efisiensi ekonomi; $\mathrm{bi}=$ Elastisitas produksi; $\mathrm{Y}=$ Jumlah produksi, $\mathrm{HY}_{\mathrm{Y}}=$ Harga produk; $\mathrm{Hxi}=$ Harga faktor produksi.

Untuk mengetahui penggunaan faktor produksi yang optimum digunakan rumus :

$$
\mathrm{Xi}^{*}=\frac{\mathrm{bi} \cdot \mathrm{Y} \cdot \mathrm{Hy}}{\mathrm{Hxi}}
$$

Dimana: $\mathrm{Xi}^{*}=$ Jumlah faktor produksi yang optimum.

Rumus ini diturunkan dari kriteria yang tetap mengkondisikan penggunaan faktor produksi optimum (efisien secara ekonomi ) yaitu pada saat $\mathrm{NPM}_{\mathrm{X}_{\mathrm{i}}} / \mathrm{H}_{\mathrm{X}_{\mathrm{i}}}=1$ atau $\mathrm{NPM}_{\mathrm{X}_{\mathrm{i}}}=\mathrm{H}_{\mathrm{X}_{\mathrm{i}}}$, dimana $\mathrm{Xi}^{*}$ dijadikan sebagai variabel yang akan dicari nilai optimumnya dengan memperhatikan bi, produk (Y), harga produk (Hy) dan harga faktor produksi (Hxi).

Doll dan Orazem (1978) menyatakan bahwa dalam terminologi ekonomi jumlah yang paling menguntungkan disebut sebagai jumlah yang optimum. Dalam terminologi tersebut, tujuan yang ingin dicapai seorang produsen sebagai manajer adalah efisiensi ekonomi, yang bisa didekati dengan ukuran maksimasi pendapatan. Oleh karena itu istilah dari suatu keadaan produksi optimal yang memberikan pendapatan maksimum sehingga tercapai efisiensi ekonomi, merupakan istilah yang memberikan pengertian sama yang dapat dipakai berganti-ganti. Menurut Soekertawi (1990) dengan mengetahui tingkat efisiensi ekonomi akan tergambar jumlah input optimal dalam kegiatan produksi. Kemudian oleh Teken dan Asnawi, (1977) dinyatakan bahwa kriteria tingkat produksi optimum secara ekonomis dapat dihitung dengan pendekatan pendapatan maksimum dari suatu usaha produksi. 


\section{HASIL DAN PEMBAHASAN}

\section{Karakteristik Petani Responden}

Petani responden dalam penelitian ini berjumlah 55 petani kakao yang diperoleh dari 2 desa, yaitu Desa Pulau Mentaro dan Desa Betung. Karakterisitik petani responen menggambarkan identitas petani , mencakup umur petani, tingkat pendidikan, jumlah anggota keluarga dan pengalaman berusahatani, yang dapat dilihat pada Tabel 1 .

Tabel 1. Karakteristik Petani Responden Berdasarkan Usia Petani, Tingkat Pendidikan, Pengalaman Berusahatani dan Jumlah Anggota Keluarga di Daerah Penelitian Tahun 2019

\begin{tabular}{|c|c|c|c|c|}
\hline No & Karakteristik & Satuan & Kisaran & Rata-rata \\
\hline 1. & Umur Petani & Tahun & $30-67$ & 47 \\
\hline 2. & Tingkat Pendidikan & $\begin{array}{l}\text { Pendidikan } \\
\text { Formal }\end{array}$ & $\begin{array}{l}\text { Tamat SD- } \\
\text { Tamat SLTP }\end{array}$ & SD \\
\hline 3. & $\begin{array}{l}\text { Jumlah Anggota } \\
\text { Keluarga }\end{array}$ & Orang & $2-6$ & 3 \\
\hline 4. & $\begin{array}{l}\text { Pengalaman } \\
\text { Berusahatani }\end{array}$ & Tahun & $9-14$ & 12 \\
\hline
\end{tabular}

Sumber: Hasil olah data primer

Berdasarkan Tabel 1 dapat dikemukakan bahwa rata-rata umur petani responden di daerah penelitian adalah 47 tahun dan umur dengan usia tersebut tergolong petani yang berumur produktif. Menurut Soeharjo dan Patong (1973)bahwa umur produktif adalah mereka yang bekerja pada umur antara 1555 tahun, dimana pada usia tersebut seseorang dapat dikatakan memiliki kemampuan fisik yang baik untuk mengelola usahanya.

Pendidikan formal yang terbesar jumlahnya diikuti petani responden adalah tingkat Sekolah Dasar (SD) kemudian SLTP. Ini menunjukan wajib belajar minimal 6 tahun dan 9 tahun yang disyaratkan pemerintah telah diikuti oleh petani di daerah penelitian. Dikemukakan Fadholi Hernanto (1996), kemampuan baca dan menulis merupakan potensi dasar bagi petani resonden untuk mengenal inovasi dan kemungkinan mengadobsinya.

Jumlah anggota keluarga adalah banyaknya orang yang menjadi beban atau tanggungan rumah tangga. Hasil penelitian menunjukkan rata-rata anggota rumah tangga petani responden di daerah penelitian berjumlah 3 orang.

Pengalaman berusahatani adalah pengalaman petani berusahatani kakao yang dinyatakan dalam tahun. Rata-rata pengalaman petani berusahatani kakao adalah 12 tahun. Lamanya pengalaman ini berkaitan dengan kriteria petani yang dipilih menjadi responden, yaitu petani yang memiliki kakao berumur berkisar antara 9 sampai dengan 14 tahun. Sehingga disamping memperhatikan 
tingkat pengalaman petani, dengan umur tanaman yang optimal diharapkan petani dapat memperoleh produksi yang maksimal.

\section{Penggunaan Faktor Produksi Pada Usahatani Kakao}

Di daerah penelitian lahan petani responden merupakan lahan milik sendiri. Rata-rata luas lahan kakao yang dimiliki adalah 1,23 hektar dengan kisaran yang terkecil berada pada luas 0,5 hektar dan yang terbesar 3 hektar. Besarnya penggunaan faktor produksi lainnya yaitu tenaga kerja, pupuk dan obat-obatan per luas tanam dan per hektar dapat dilihat pada tabel berikut.

Tabel 2. Rata-rata Penggunaan Faktor Produksi pada Usahatani Kakao dengan Umur Tanaman 9-14 tahun di Daerah Penelitian, Tahun 2019

\begin{tabular}{lrr}
\hline \multicolumn{1}{c}{ Faktor produksi } & $\begin{array}{c}\text { Penggunaan per luas } \\
\text { tanam }\end{array}$ & Penggunaan per hektar \\
\hline Tenaga kerja (HOK) & 87,16 & 70,86 \\
Pupuk (Kg) & $1.172,00$ & 952,90 \\
Obat-obatan (Liter) & 10,61 & 8,63 \\
\hline
\end{tabular}

Sumber: Hasil olah data primer

Tenaga kerja yang digunakan petani adalah tenaga kerja dalam keluarga (TKD) dan luar keluarga (TKL) yang diupah Rp 80.000,00 per hari. Jenis pupuk yang digunakan adalah pupuk urea, TSP dan KCL dengan komposisi 36,43 \% urea, 35,50 \% TSP dan 28,07 \% KCL. Obat-obatan yang digunakan berupa pestisida cair matador, sidametrin dan gramokson. Komposisi penggunaannya adalah $35,46 \%$ matador, $28,62 \%$ sidametrin dan $35,92 \%$ gramaxon.

\section{Optimalisasi Penggunaan Faktor Produksi pada Usahatani Kakao}

Optimasi pada penelitian ini merupakan upaya pendekatan untuk mencari jumlah optimum pengunaan faktor produksi pada usahatani kakao yang berada pada umur tanaman yang optimal dengan kisaran 9 -14 tahun. Penggunaan faktor produksi dikonversikan dalam satuan luas per hektar. Sehingga dalam analisis hubungan fisik input-output (fungsi produksi) terdapat 4 variabel yang akan dilihat pengaruhnya yaitu tenaga kerja $\left(\mathrm{X}_{1}\right)$, pupuk $\left(\mathrm{X}_{2}\right)$ dan obat-obatan $\left(\mathrm{X}_{3}\right)$ sebagai sebagai variabel bebas dan produksi per hektar (Y) sebagai variabel terikat. Hasil regresi pengaruh dari variabel-variabel tersebut terhadap produksi kakao disajikan pada tabel 3.

Dari tabel 3, secara simultan semua faktor produksi (tenaga kerja, pupuk dan obat-obatan ) berpengaruh terhadap produksi kakao. Nilai F hitung adalah 69,03. Besaran ini menunjukan nilai yang signifikan. Tabel 3 juga menunjukkan bahwa koefisien determinasi $\left(R^{2}\right)$ menunjukan angka sebesar 0,413 yang berarti4 $1,3 \%$ variasi produksi/ha dari tanaman kakao dapat dijelaskan oleh variasi tenaga kerja $\left(\mathrm{X}_{1}\right)$, pupuk $\left(\mathrm{X}_{2}\right)$ dan obat-obatan $\left(\mathrm{X}_{3}\right)$ sedangkan sisanya sebesar 
$58,7 \%$ dijelaskan oleh faktor lain yang tidak termasuk ke dalam model yang dianalisis, yaitu lahan.

Tabel 3. Koefisien Regresi Penggunaan Faktor Produksi/hektar/tahun pada Usahatani Kakao dengan Umur Tanaman 9-14 tahun di Daerah Penelitian, Tahun 2019

\begin{tabular}{lcc}
\hline \multicolumn{1}{c}{ Variabel independent (Xi) } & Koefisien Regresi & Probability \\
\hline Ln X $(\mathrm{TK})$ & 0,537012 & 0,0000 \\
Ln X 2 (Pupuk) & 0,168859 & 0,0694 \\
Ln X3 (Obat2an) & 0,029094 & 0,7027 \\
C (konstanta) & 3,518798 & 0.0002 \\
R-squared (R $\left.{ }^{2}\right)=0,413$ & & \\
F hitung = & 69,03 & 0,0000 \\
\hline
\end{tabular}

Sumber: Hasil olah data primer

Ketika faktor produksi lahan dimasukan kedalam model maka diperoleh koefisien regres idalam model tersebut yang bernilai negative yaitu pada faktor produksi pupuk dan obat-obatan. Oleh karena itu, lahan tidak dimasukan sebagai variabel dalam model ini. Koefisien regresi dalam model menunjukan nilai elastisitas produksi (bi) dari penggunaan faktor produksi. Doll dan Orazem (1978) menyatakan besarnya elastitas produksi yang memenuhi syarat terpenuhinya efisiensi ekonomi adalah $0 \leq b_{i} \leq 1$, dan bersifat rasional. Penggunaan faktor produksi yang memenuhi syarat itu berada pada tahap/daerah produksi II.

Pengaruh secara parsial menunjukan bahwa faktor produksi tenaga kerja memiliki probabilitas yang kecil dari 0,05 (prob. < 0,05) yang artinya penambahan $1 \%$ tenaga kerja $\left(X_{1}\right)$ secara individu berpengaruh nyata terhadap peningkatan produksi kakao/hektar sebesar nilai koefisien regresinya. Di daerah penelitian potensi tenaga kerja yang dimiliki petani responden cukup besar karena dari hasil penelitian diperoleh bahwa rata-rata jumlah anggota keluarga yang dimiliki petani adalah 3 orang. Setiap penambahan tenaga kerja akan menyebabkan kegiatan pemeliharaan usahatani kakao dapat terlaksana dengan baik. Kegiatan penyiangan, pemupukan, pengendalian hama penyakit, penanganan panen dan pasca panen yang tepat waktu dapat meningkatkan produksi kakao sehingga berimplikasi terhadap peningkatan pendapatan petani.

Hasil penelitian ini sejalan dengan penelitian sebelumnya yang dilakukan oleh Jalil K.Gugere, $d k k$ (2016), tentang Analisis produksi dan pendapatan usahatani kakao di Desa Tongoa Kecamatan Palolo Kabupaten Sigi, yang menyatakan bahwa jumlah tenaga kerja mempunyai pengaruh positif terhadap peningkatan produksi. Apabila tenaga kerja ditambah sebesar $1 \%$ maka produksi kakao akan meningkat sebesar sebesar 0,224 \%. Kemudian juga sesuai dengan penelitian Fandri Tangku, $d k k$ (2015), tentang Analisis efisiensi 
penggunaan input produksi usahatani kakao di Desa Kewende Kecamatan Poso Pesisir Utara Kabupaten Poso. Dari hasil penelitian tersebut diperoleh koefisien regresi tenaga kerja sebesar 0,236 dan berpengaruh positif terhadap produksi.

Faktor produksi pupuk $\left(\mathrm{X}_{2}\right)$ dan obat-obatan $\left(\mathrm{X}_{3}\right)$ secara individu tidak berpengaruh nyata terhadap peningkatan produksi kakao/hektar, hal ini ditunjukan probabilita kedua variabel tersebut lebih besar dari 0,05 (prob. > $0,05)$. Tidak berpengaruhnya secara individu faktor produksi pupuk terhadap peningkatan produksi kakao/hektar diduga karena penggunaannya oleh petani responden jumlahnya sudah melebihi dosis yang dianjurkan. Di daerah penelitian rata-rata dosis pupuk apabila dikonversikan dalam gram/pohon/tahun adalah Urea 510,40 gram, TSP 497, 37 gram dan KCL 393,35 gram. Sedangkan dosis anjuran pemupukan tanaman kakao di atas umur 6 tahun untuk setiap pohon per tahun adalah Urea 222 gram, SP-36 207 gram atau TSP 180 gram dan KCL 331,8 gram. (Karmawati, E. $d k k$, 2010).

Penelitian ini sejalan dengan penelitian yang dilakukan oleh Titis Luttiyana dan Yuli Hariyati (2019) tentang Efisiensi penggunann input dan skala produksi usahatani komoditas kakao di Kecamatan Udanawu KabupatenBlitar, yang menyatakan bahwa pupuk berpengaruh secara tidak nyata pada taraf $95 \%$ pada produksi kakao, namun pada taraf kepercayaan 90 $\%$ penggunaan pupuk terhadap produksi kakao berpengaruh secara nyata.

Pengendalian hama dan penyakit biasanya dilakukan petani responden 2 kali dalam 1 bulan. Pemberantasan hama dan penyakit pada tanaman kakao sangat penting dilakukan, karena hama penyakit merupakan salah satu keluhan bagi petani di daerah penelitian. Namun dengan jumlah penggunaan obatobatan oleh petani responden sebanyak 8,63 liter per tahun/hektar ternyata tidak memberikan pengaruh terhadap peningkatkan produksi kakao/hektar.

Hasil penelitian ini sejalan dengan penelitian Fandri Tangku, (2015) $d k k$, tentang Analisis efisiensi penggunaan input produksi usahatani kakao di Desa Kewende Kecamatan Poso Pesisir Utara kabupaten Poso, yang menyatakan pestisida berpengaruh tidak nyata terhadap produksi kakao karena $t$ hitung lebih kecil dari $t$ tabel pada taraf a $1 \%$. Kemudian sejalan juga dengan penelitian Dewi Mulia Sari (2017), $d k k$ tentang Analisis efisiensi teknis perkebunann kakao rakyat di Provinsi Lampung, yang menyatakan bahwa insektida tidak berpengaruh nyata terhadap peningkatan produksi kakao.

Namun hasil penelitian ini tidak sesuai dengan penelitian yang dilakukan Titis Luttiyana dan Yuli Hariyati (2019) tentang Efisiensi penggunann input dan skala produksi usahatani komoditas kakao di Kecamatan Udanawu Kabupaten Blitar. Dari penelitian tersebut diperoleh bahwa input pestisida berpengaruh terhadap produksi kakao dengan koefisien regresi sebesar $-0,007 \%$, yang artinya setiap penambahan pestisida akan menurunkan produksi kakao sebesar nilai koefisien regresi tersebut. Keadaan ini menunjukan bahwa penguasaan dan 
penerapan teknologi produksi yang dilakukan oleh setiap petani di tiap daerah berbeda-beda.

Pada penelitian ini hasil penjumlahan koefisien regresi masing-masing penggunaan faktor produksi diperoleh ep $=0,725$ yang berarti penggunaan faktor produksi ( tenaga kerja, pupuk dan obat-obatan ) dalam menghasilkan produksi kakao/hektar pada daerah penelitian berada di tahap produksi yang efisien secara fisik dan memenuhi kondisi syarat atau kondisi perlu (necessary condition) dalam kajian efisiensi ekonomi. Kondisi syarat hanya dikaitkan dengan hubungan fisik dan bersifat rasional.

Jika ditilik dari sudut teknis, kondisi syarat itu saja telah cukup untuk mengetahui efisiensi teknis dari penggunaan faktor produksi dalam menghasilkan produk kakao/hektar. Hal ini juga sejalan dengan pernyataan A.G Kartasapoetra, (1988) bahwa, suatu fungsi produksi bisa menggambarkan metode produksi yang efisien secara teknis dalam penggunaan sumberdaya pada suatu perusahaan. Akan tetapi dalam hubungannya untuk mengetahui jumlah optimum (efisiensi ekonomi) dari faktor produksi, maka dibutuhkan kondisi pelengkap (sufficient condition). Kondisi ini acapkali disebut sebagai indikator pilihan yang bisa membantu petani /manajer dalam menentukan jumlah optimum dari input (Doll dan Orazem, 1978). Indikator pilihan usaha yang didasarkan pada tujuan untuk memaksimum pendapatan adalah harga dari faktor produksi dan produk $\left(\mathrm{H}_{\mathrm{X}_{\mathrm{i}}}\right.$ dan $\left.\mathrm{H}_{\mathrm{Y}}\right)$ dalam suatu proses produksi (Teken dan Asnawi, 1977).

Penggabungan efisiensi teknis dan harga merupakan efisiensi ekonomi dari penggunaan faktor produksi (Soekertawi 1989) Efisiensi ekonomi dari penggunaan faktor produksi dihitung dari produk marjinal penggunaan faktor produksi ke-i $\left(\mathrm{PM}_{\mathrm{X}_{\mathrm{i}}}\right)$ dan rasio $\mathrm{H}_{\mathrm{X}_{\mathrm{i}}} / \mathrm{H}_{\mathrm{Y}}$. Dikatakan efisien apabila penggunaan faktor produksi sedemikian rupa sehingga menghasilkan produksi dimana tercapai $\mathrm{PM}_{\mathrm{X}_{\mathrm{i}}}=\mathrm{H}_{\mathrm{X}_{\mathrm{i}}} / \mathrm{H}_{\mathrm{Y}}$. Rumus ini dapat diturunkan menjadi $\mathrm{H}_{Y} \cdot \mathrm{PM}_{\mathrm{X}_{\mathrm{i}}}=\mathrm{H}_{\mathrm{X}_{\mathrm{i}}}$ atauacapkali sering dipakai $\mathrm{NPM}_{\mathrm{i}} / \mathrm{H}_{\mathrm{i}}=1$.

Tingkat efisiensi ekonomi dari penggunaan faktor produksi tenaga kerja $\left(X_{1}\right)$, pupuk $\left(X_{2}\right)$ dan obat-obatan $\left(X_{3}\right)$ dalam menghasilkan produk kakao per hektar di daerah penelitian dapat dilihat pada tabel 4 .

Tabel 4 menjelaskan bahwa penggunaan faktor produksi tenaga kerja tenaga $\left(X_{1}\right)$, pupuk $\left(X_{2}\right)$ dan obat-obatan $\left(X_{3}\right)$ pada usahatani kakao per hektar belum mencapai efisiensi ekonomi, karena angka indeks menunjukan $\mathrm{NPM}_{\mathrm{x}_{\mathrm{i}}} / \mathrm{H}_{\mathrm{X}_{\mathrm{i}}}$ masing-masing faktor produksi lebih besar dari nilai 1 (NPM $\mathrm{x}_{\mathrm{i}} / \mathrm{H}_{\mathrm{X}_{\mathrm{i}}}$ $>1)$. Hal ini memberikan indikasi bahwa penggunaan tenaga kerja $\left(X_{1}\right)$, pupuk $\left(X_{2}\right)$ dan obat-obatan $\left(X_{3}\right)$ pada usahatani kakao di daerah penelitian memiliki potensi untuk ditambah guna mendapatkan hasil kakao per hektar yang optimal, yang dapat memberikan pendapatan maksimum. 
Tabel 4. Efisiensi penggunaan Faktor Produksi per hektar Usahatani Kakao pada Umur Tanaman 9-14 tahun di Daerah Penelitian, Tahun 2019

\begin{tabular}{lrrr}
\hline \multicolumn{1}{c}{ Komponen yang diketahui } & $\begin{array}{c}\text { Tenaga } \\
\text { Kerja/HOK }\end{array}$ & Pupuk/Kg & Obat-obatan/liter \\
\hline Produk kakao $(\mathrm{Y})=1.241,37 \mathrm{~kg}$ & & & \\
Hy $=\mathrm{Rp} 28.620,00 / \mathrm{kg}$ & & & \\
Penggunaan faktor produksi (Xi) & 70,86 & 952,9 & 8,63 \\
Koefisien regresi (ep) & 0,537012 & 0,168859 & 0,029094 \\
$\mathrm{H}_{\mathrm{x}}(\mathrm{Rp} /$ satuan) & $80.000,00$ & $2.616,00$ & $108.906,06$ \\
$\mathrm{NPM} \mathrm{x}_{\mathrm{i}} / \mathrm{H}_{\mathrm{i}}$ & 3,37 & 2,41 & 1,10 \\
Simpulan & Belum efisisien & Belum efisien & Belum efisien \\
\hline
\end{tabular}

Sumber: Hasil olah data primer, 2019

Penggunaan biaya atau harga yang dikeluarkan dari faktor produksi tenaga kerja, pupuk dan obat-obatan di daerah penelitian masih rendah sehingga secara ekonomi faktor produksi tersebut masih bisa ditingkatkan penggunaannya agar kegiatan usahatani kakao di daerah penelitian bisa dilakukan dengan baik untuk menghasilkan produksi yang optimal dan berimplikasi terhadap peningkatan pendapatan. Hasil penelitian ini sejalan dengan penelitian dari Fandri Tangku (2015) $d k k$, dimana faktor produksi tenaga kerja, pupuk, pestisida penggunaannya masih belum efisien ditinjau dari sisi harga/biaya yang dikeluarkan, sehingga penggunaannya dapat ditambah agar pendapatan petani kakao di desa Kawende menjadi maksimal. Kemudian hasil yang sama juga pada penelitian Dahrul Yani. dkk, 2017, yang menyatakan bahwa faktor produksi tenaga kerja dan modal pada usahatani kakao di Kecamatan Bandar Baru Kabupaten Pidie Jaya secara ekonomi pengunaannya belum efisien dan masih perlu untuk ditingkatkan.

\section{Penggunaan Faktor Produksi yang Optimal}

Dalam penelitian ini untuk menentukan berapa besar faktor produksi perlu ditambah agar produksi kakao per hektar dapat memberikan pendapatan maksimum, tetap menggunakan rumus $\mathrm{NPM}_{\mathrm{x}_{\mathrm{i}}} / \mathrm{H}_{\mathrm{x}_{\mathrm{i}}}=1$. Angka indeks rasio $=$ 1 merupakan batas ukuran bahwa penggunaan input adalah efisien. Berdasarkan rumus ini, variabel tenaga kerja $\left(\mathrm{X}_{1}\right)$, pupuk $\left(\mathrm{X}_{2}\right)$ dan obat-obatan $\left(\mathrm{X}_{3}\right)$ merupakan variabel yang akan dicari/dihitung batas optimal penggunaannya $\left({ }^{*}\right)$, dengan memperhatikan beberapa komponen yang tetap, yaitu diketahui harga jual produk $\left(\mathrm{H}_{\mathrm{Y}}\right)$, harga jual faktor produksi $\left(\mathrm{H}_{\mathrm{x}_{\mathrm{i}}}\right)$ dan bi (ep) dari masing-masing faktor produksi. Jumlah optimal dari penggunaan faktor produksi pada usahatani kakao per hektar dapat dilihat pada Tabel 5.

Berdasarkantabel 5 dapat dijelaskanbahwa agar maksimisasi pendapatan/tahun pada usahatani kakao/hektar dapat tercapai, maka penggunaan faktor produksi tenaga kerja/tahun/hektar $\left(\mathrm{X}_{1}\right)$ dapat ditambah 
hingga sebesar $238,5 \mathrm{HOK}$. Sedangkan penggunaan pupuk $\left(\mathrm{X}_{2}\right)$ dapat ditambah hingga sebesar $2.293,28 \mathrm{~kg} /$ tahun/hektar dan obat-obatan $\left(X_{3}\right)$ ditambah menjadi 9,50 liter. Melebihi dari penggunaan batas optimal maka penggunaan faktor produksi tenaga kerja, pupuk dan obat-obatan pada usahatani kakao menjadi tidak efisien karena $\mathrm{NPM}_{\mathrm{x}_{\mathrm{i}}}<\mathrm{H}_{\mathrm{x}_{\mathrm{i}}}$.Tambahan biaya faktor produksi pada kriteria ini akan melebihi tambahan penerimaan dari usahatani kakao. Biaya faktor produksi yang dikeluarkan petani responden akan menjadi lebih besar, sehingga penambahan dalam penggunaan faktor produksi tersebut perlu dihentikan.

Tabel 5. Jumlah Optimal Penggunaan Tenaga Kerja, Pupuk dan Obat-obatan pada Usahatani Kakao/hektar dengan Umur Tanaman 9-14 Tahun di Daerah Penelitian, Tahun 2019

\begin{tabular}{lrrr}
\hline \multicolumn{1}{c}{ Komponen yang diketahui } & Tenaga kerja/HOK & Pupuk/Kg & \multicolumn{1}{c}{$\begin{array}{c}\text { Obat- } \\
\text { obatan/liter }\end{array}$} \\
\hline Komponen tetap, & & & \\
Produk kakao $(\mathrm{Y})=1.241,37 \mathrm{~kg}$ & & & \\
$\mathrm{H}$ = Rp 28.620/kg & & & \\
Hxi $(\mathrm{Rp} /$ satuan) & $80.000,00$ & $2.616,00$ & $108.906,06$ \\
Koefisien regresi (ep) & 0,537012 & 0,168859 & 0,029094 \\
Jumlah optimal(Xi) & 238,50 & $2.293,28$ & 9,50 \\
\hline
\end{tabular}

Sumber: Hasil olah data primer, 2019

Perbandingan penggunaan faktor produksi pada jumlah yang optimal dengan penggunaan faktor produksi aktual oleh petani pada usahatani kakao di daerah penelitian dapat dilihat pada Tabel 6 .

Tabel 6. Jumlah Optimal dan Aktual Penggunaan Faktor Produksi pada Usahatani Kakao/hektar/tahun dengan Umur Tanaman 9-14 tahun di Daerah Penelitian, Tahun 2019

\begin{tabular}{lccrr}
\hline \multicolumn{1}{c}{ Faktor produksi } & Xi $^{*}$ (optimal) & Xi (aktual) & Marjin & $\%$ \\
\hline Tenaga Kerja $\left(\mathrm{X}_{1}\right) / \mathrm{HOK}$ & 238,50 & 70,86 & 167,64 & 236,24 \\
Pupuk $\left(\mathrm{X}_{2}\right) / \mathrm{Kg}$ & $2.293,28$ & 952,90 & $1.340,38$ & 140,66 \\
Obat-obatan $\left(\mathrm{X}_{3}\right) /$ Liter & 9,50 & 8,63 & 0,87 & 10,08 \\
\hline
\end{tabular}

Sumber: Hasil olah data pimer, 2019

Tabel 6 dapat memberikan gambaran bahwa curahan kerja aktual yang dilakukan petani responden di daerah penelitian masih rendah dan dari hasil optimum petani berpotensi untuk meningkatkan penggunaan kerja. Menurut Tohir, K (1983) perkiraan kebutuhan tenaga kerja tanaman tahunan (keras) seperti kopi (sumatera) adalah 2.400 jam per hektar per tahun. Apabila satu hari 
kerja dibutuhkan waktu 8 jam maka kebutuhan tenaga kerja komoditi itu adalah 300 hari orang kerja. Dilihat dari kegiatan usahataninya, tanaman kopi dan kakao merupakan tanaman yang memiliki kemiripan.

Pemeliharaan merupakan kegiatan yang penting bagi pertumbuhan tanaman kakao yang telah menghasilkan. Kegiatan ini meliputi pemangkasan, penyiangan, pemupukan, pengendaliah hama penyakit dan panen. Dari semua kegiatan ini, pekerjaan yang paling sedikit dilakukan petani responden di daerah penelitian adalah pemangkasan, kemudian diikuti dengan pekerjaan pemupukan dan pengendalian hama penyakit. Dan yang paling besar menjadi perhatian petani adalah panen dan pasca panen.

Menurut Anisaziiz (2015) pemangkasan merupakan bagian yang penting untuk pertumbuhan kakao. Pada dasarnya pemangkasan kakao untuk memperoleh nilai indeks luas daun optimal agar hasil bersih fotosintesa menjadi maksimal. Ini tentunya akan berpengaruh langsung terhadap produksi kakao. Sjafarudin dan Sulle (2003) menyatakan bahwa, pemangkasan tanaman kakao juga merupakan salah satu cara untuk mengendalikan hama penggerek buah kakao selain dilakukan dengan cara kimiawi. Kemudian oleh Tohir, K. (1983) dikatakan bahwa setiap jenis tanaman memiliki kepekaan yang berbeda atas intensifikasi tenaga kerja. Jenis tanaman seperti teh, kopi dan kakao tidak akan mendatangkan produksi yang layak tanpa adanya intensifikasi pengelolaan lahan, pemeliharaan dan pemupukan.

Pemupukan dilakukan petani agar produksi tanaman bisa memberikan hasil yang maksimum. Pada tabel 6 menunjukan bahwa potensi peningkatan jumlah optimal pupuk pada usahatani kakao juga cukup besar.Namun demikian, walaupun secara ekonomi ditinjau dari harga/ biaya pupuk yang dikeluarkan masih rendah dan jumlahnya dapat ditingkatkan, maka dalam pemberian pupuk pada usahatani kakao di daerah penelitian secara teknis perlu dipertimbangkan batas dosis yang dianjurkan. Hal ini karena penggunaan aktual pupuk yang dilakukan petani untuk setiap pohon kakao sudah melebihi dosis yang dianjurkan. Sementara itu, penambahan jumlah optimal obatobatan paling kecil dibandingkan faktor produksi tenaga kerja dan pupuk. Penggunaan aktual obat-obatan di daerah penelitian oleh petani responden secara ekonomi dapat dinyatakan relatif lebih efisien.

Menurut M.Hidayanto. $d k k$, (2016) beberapa faktor pengungkit diantaranya yang mempengaruhi produksi kakao adalah rata-rata umur tanaman, tingkat serangan hama penyakit dan tingkat penyerapan tenaga kerja. Umur tanaman merupakan atribut yang paling sensitive. Tanaman kakao yang umurnya berkisar (15- 20) tahun di atas umur optimal (9-14) tahun, produktivitasnya mulai menurun, mudah terserang hama penyakit dan pemeliharann (pemangkasan, pemupukan, pemberantasan hama penyakit) menjadi kurang optimal. Oleh karena itu pada masa mendatang untuk keberlanjutan usahatani kakao, maka perlu dilakukan antara lain peremajaan 
tanaman, pemberantasan hama penyakit yang lebih intensif, perbaikan dalam hal teknik budidaya dan pemberdayaan petani melalui peningkatan pengetahuan dan keterampilan petani dalam teknologi budidaya.

\section{SIMPULAN DAN SARAN}

\section{Simpulan}

Simpulan yang dapat diperoleh bahwa : (1) Penggunaan faktor produksi tenaga kerja, pupuk dan obat-obatan secara serempak berpengaruh terhadap produksi kakao. Secara parsial tenaga kerja berpengaruh terhadap kenaikan produksi kakao/hektar/tahun, sedangkan pupuk dan obat-obatan tidak memberikan pengaruh terhadap produksi. Penambahan pupuk dan obat-obatan secara teknis tidak menaikan jumlah produksi kakao karena penggunaannya terutama faktor produksi pupuk sudah melebih dari anjuran. (2) Penggunaan tenaga kerja, pupuk dan obat-obatan belum efisiensi ekonomi dan berpotensi untuk ditambahkan. (3) Dari hasil optimasi, penggunaan kerja dapat ditingkatkan hingga batas optimal 238,5 HOK/hektar/tahun. Sedangkan penggunaan pupuk $\left(X_{2}\right)$ dapat ditambah hingga sebesar 2.293,28 $\mathrm{kg} /$ tahun/hektar dan obat-obatan dapat ditingkatkan petani hingga 9,5 liter.

\section{Saran}

Untuk meningkatkan produksi dan pendapatan usahatani kakao/hektar/tahun maka diharapkan petani bisa melakukan pemeliharaan kebun kakao secara intensif mulai dari pekerjaan pemangkasan, penyiangan, mulching, pengendalian hama penyakit dan pemanenan dengan tetap memperhatikan kesesuaian dengan kriteria matang panen.

Penggunaan faktor produksi tenaga kerja dan obat-obatan diharapkan bisa dipertimbangkan petani untuk ditambah sampai batas optimal sehingga efisiensi ekonomi dapat tercapai. Penggunaan tenaga kerja perlu ditambah terutama sekali pada pekerjaan pemangkasan dan penyiangan agar hasil bersih fotosintesa menjadi maksimal, dan pekerjaan ini akan berpengaruh langsung terhadap produksi dan pada akhirnya terhadap pendapatan usahatani kakao

\section{DAFTAR PUSTAKA}

A.G. Kartasapoetra. 1988.Pengantar Ekonomi Produksi Pertanian. PT Bina Aksara, Jakarta.

Anis Aziiz. 2015. Pemangkasan, Penyiangan dan Penutupan Kakao. Departemen Agronomi dan Hortikultura (www.agrohort.ipb.ac.id).

Dinas Perkebunan Provinsi Jambi. 2015. Statistik Tanaman Perkebunan /Tanaman kakao Provinsi Jambi. Provinsi Jambi. 
Dinas Kehutanan dan Perkebunan Kabupaten Muaro Jambi. 2015. Statisitik Tanaman Perkebunan/Tanaman kakao Kabupaten Muaro Jambi. Jambi.

Doll, P.J and Orazem, F. 1978. Production Economics. Theory with and applications by Jhon Wiley \& Son, Inc. USA.

Dahrul Yani, Suyanti Kasimin dan Indra. 2017. Analisis Efsiensi dan FaktorFaktor yang Mempengaruhi Produksi Kakao Di Kecamatan Bandar Baru Kabupaten Pidie Jaya. Jurnal Ilmiah Mahasiswa Unsyiah. 2(1):67-76.

Dewi Mulia Sari, Anna Fariyanti dan Netti Tinaptrilla. 2017. Analisis Efisiensi Teknis Perkebunan Kakao Rakyat Di Provinsi Lampung.Jurnal Tanaman Industri dan Penyegar (Journal of Industrial and Beverage Crops). 4(1): 31-40. Fandri Tangku, Rukavina Bakhs dan Dance Tangkesalu. 2015. Analisis Efisensi Penggunaan Input Produksi Usahatani Kakao Di Desa Kawende Kecamatan Poso Pesisir Utara Kabupaten Poso. Jurnal Agrotekbis. 3(2):222-230.

Jalil K. Gugere, Made Antara dan Max Nur Alam. 2016. Analisis Produksi dan

Pendapatan Usahatani Kakao di Desa Tongoa Kecamatan Palolo Kabupaten Sigi.Jurnal Agroland. 23(1):1-10.

M. Hidayanto, dkk. 2016. Analisis Keberlanjutan Perkebunan Kakao Rakyat Di Kawasan Perbatasan Pulau Sebatik Kabupaten Nunukan Provisi Kalimantan Timur.Jurnal Agro Ekonomi e-jurnal. litbang. pertanian.go.id.

Teken, I.B dan Asnawi, S. 1977. Teori Ekonomi Mikro. Institut Pertanian Bogor.

Titis Luttiyana dan Yuli Haryati, 2019. Efisiensi Penggunaan Input dan Skala Produksi Usahatani Komoditi Kakao di Kecamatan Udanawu Kabupaten Blitar.Jurnal Agribisnis Indonesia. 7(1):53-62.

Fadholi Hernanto, 1996. Ilmu Usahatani. Penebar Swadara, Jakarta.

Karmawati, E. Dkk. 2010. Budidaya dan Pasca Panen Kakao. Pusat Penelitian dan Pengembangan Perkebunan. Bogor.

Oktavia,Ayu Rahayu. 2016. Analisis Pendapatan Usahatani Tanaman Kakao di

Kecamatan Kumpeh Kabupaten MuaroJambi. Skripsi Fakultas Peranian Universitas Jambi, Jambi.

Soeharjo dan Patong, 1973. Sendi-Sendi Pokok Ilmu Usahatani, Depatermen Ilmu-ilmu Sosial Ekonomi Pertanian, Fakultas Pertanian, IPB.

Siregar, Tumpal. 1989. Budidaya.Pengolahan dan Pemasaran Coklat. Penebar Swadaya, Jakarta.

Soekertawi. 1989.Prinsip Dasar Ekonomi Pertanian, Teori dan Aplikasi. Rajawali Press, Jakarta.

. 1990. Teori Ekonomi Produksi dan Aplikasinya. PT. Raja Grasindo Persada, Jakarta.

Sokertawi. 1994.Teori Ekonomi Produksi dengan Pokok Bahasan Analisis Fungsi CobbDouglas. PT Raja Grafinso Persada, Jakarta. 
Sjafaruddin, M dan A Sulle. 2003. Pengelolaan Hama Penggerek Buah Kakao di Sulawesi Tenggara. Prosiding Penerapan Teknologi Spesifik Lokasi dalam Mendukung Pengembangan Sumberdaya Pertanian. Puslitbang Sosial Ekonomi Bogor.

Tohir, K. 1983. Seuntai Pengetahuan tentang Usahatani Indonesia. Bina Aksara, Jakarta. 